Vol 13, Issue 9, 2020

\title{
MATERNAL AND FETAL TOXICITY-INDUCED BY NICKEL OXIDE NANOPARTICLES ADMINISTRATION IN ALBINO RATS DURING GESTATION
}

\author{
HAMIDA HAMDI ${ }^{1,2 *}$ \\ ${ }^{1}$ Department of Zoology, Faculty of Science, Cairo University, Egypt. ²Department of Biology, Faculty of Science, Taif University, \\ Saudi Arabia. Email: hamida@sci.cu.edu.eg
}

Received: 06 May 2020, Revised and Accepted: 22 June 2020

\section{ABSTRACT}

Objective: Despite the widespread of nickel oxide nanoparticles (NiO NPs) and their benefits in all fields, they have many negative effects on human life, especially expectant mothers and their fetus. The purpose of this study was to investigate the possible maternal and developmental toxicityinduced by NiO NPs administration during gestation.

Methods: Three groups of pregnant rats were administered orally during days 5-19 of gestation, the pregnant rats were haphazardly designed into three groups (six rat/group), as follows: Control group and NiO NPs administered groups, low ( $4 \mathrm{mg} / \mathrm{kg}$ ), and high (8 mg/kg) doses.

Results: NiO NPs administration resulted in severe maternal and developmental toxicity which included reduction in uterine weight, mother weight gain, the average weight of placenta, the number corpora lutea, implantation sites, and the number of live fetuses. Furthermore, high pre/ postimplantation, fetal growth retardation, and morphological and skeletal anomalies, an elevation in liver and brain DNA damage in both mother and fetus, and histopathological alterations in different tissues (placenta, liver, kidney, and brain) of pregnant rats and fetuses. Lipid peroxidation showed a significant elevation in maternal, fetal liver, and brain tissues of NiO NPs -administered rats. Furthermore, glutathione content and catalase activity were decreased in both tissues of NiO NPs-administered rats.

Conclusion: Finally, the detrimental impacts of NiO NPs in dams and fetuses probably through its potential generation of reactive oxygen species.

Keywords: Nickel oxide nanoparticles, Oxidative stress, DNA damage, Gestation, Teratogenicity.

(C) 2020 The Authors. Published by Innovare Academic Sciences Pvt Ltd. This is an open access article under the CC BY license (http://creativecommons. org/licenses/by/4. 0/) DOI: http://dx.doi.org/10.22159/ajpcr.2020.v13i9.38655

\section{INTRODUCTION}

The most widely used types of nanomaterials are the metallic nanoparticles including metallic nickel nanoparticles (Ni NPs). Ni NPs are used in many fields, including magnetic resonance imaging [1], magnetic fluids [2], catalysts [3,4], magnetic recording media [5], solar cells, lithiumion batteries, diodes, and biosensors [6], as well as in urea and glucose sensors [7,8], optoelectronics [9], magnetic hyperthermia [10], and other biomedical applications [11]. Furthermore, Nickel oxide nanoparticles (NiO NPs) have diesel-fuel additive and pigment properties [12].

Several studies revealed the detrimental health impacts of Ni NPs both in human and experimental animals such as skin allergies, lung fibrosis, lung cancer, cardiovascular diseases, hepatotoxicity [13-17], reproductive toxicity [18], and zebrafish fetal toxicity [19]. Many previous studies reported that NiO NPs when ingested through oral exposure, induced genotoxicity [20,21], multi-organ toxicity [22] in male rats. Increasing uses of NiO NPs make it widely distributed in our environment, especially in the wastewater. Hence, the potential impacts of Ni NPs on the health of humans and the environment have great concerns $[23,24]$

The excessive utilization of NiO NPs may increase the chances of exposure through dermal contact, inhalation, and oral route. The average daily intake of $\mathrm{Ni}$ from the food in the USA was estimated at 150-168 $\mu \mathrm{g}$, typical daily intake of $\mathrm{Ni}$ from drinking water was $2 \mu \mathrm{g}$ and 0.1-1 $\mu \mathrm{g}$ from air [25].

The toxicological impacts of $\mathrm{NiO}$ NPs on pregnant women and developing embryos/fetuses have limited information. Therefore, it is important to investigate the possible maternal and developmental toxicity-induced by NiO NPs administration during gestation period.

\section{METHODS}

Experimental animals

Adult female and male Swiss white albino rat (Rattus norvegicus) (7-9 weeks old, 180 g-200 g b.w) were purchased from the animal house of the King Fahd Center for Medical Research, King Abdul-Aziz University in Jeddah and were maintained on a standard lab diet in artificial illuminated and a temperature-controlled room free from any other source of chemical contamination in the Animal House Laboratory, Faculty of Science, Taif University, Saudi Arabia. The handling of the animals was carried out in strict accordance with the Guide for the Care and Use of Laboratory Animals 8 ${ }^{\text {th }}$ Edition 2011.

\section{Materials}

NiO-NPs (Cat. No. 637130) were purchased from sigma chemical company (St. Louis, MO, USA). According to the manufacturing data sheet, the particle size of the nano-sized NiO (black, 99.8\% pure) was $<50 \mathrm{~nm}$.

\section{Experiment design}

After an acclimatization period of 1 week, females were housed with males overnight in suitable cages; successful mating was determined by the presence of sperm in the vaginal smears and was designated as day zero of pregnancy. The pregnant rats were haphazardly designed into three groups (six rat/group), different doses of NiO-NPs were suspended in $1 \mathrm{ml}$ distilled water (aqueous suspension). The low dose according to Saquib et al. [22], while the high dose is doubled the low dose. The suspensions were ultrasonicated before they were administered once daily through gastric tube from $5^{\text {th }}$ until $19^{\text {th }}$ day of gestation. Group 1: Control group untreated rats. Group 2: Low-dose group, rats were administered with $4 \mathrm{mg} / \mathrm{kg}$ b.w. Group 3: High-dose group (doubled dose), rats were administered with $8 \mathrm{mg} / \mathrm{kg}$ b.w. of NiO-NPs. 
These dams were sacrificed by cervical dislocation on day 19 of gestation; the two uterine horns were removed, weight and total implantation sites, fetal mortality rate (resorbed or still birth), and living fetuses were recorded. The placentas were examined and their weights were recorded. Live fetuses were removed from the uterus and fetal body weight, body length, and tail length were recorded and examined for gross malformations [26].

\section{Skeletal examination}

Fetuses were fixed in 95\% ethyl alcohol and were stained with double staining of fetal skeletons for cartilage (Alcian blue) and bone (Alizarin red) according to the method de-scribed by Young et al. [27].

\section{Comet assay}

The alkaline comet assay was performed according to the method described by Nandhakumar et al., El-shorbagy and Hamdi [28,29] to detect DNA damage in liver and brain tissues of pregnant rats and fetuses of all different groups.

\section{Estimation of the markers of oxidative stress and antioxidants}

\section{Tissue homogenate preparation}

Liver and brain tissues of both mother and fetus of all groups were removed, washed in $0.9 \%$ saline, and then dried on filter paper. $100 \mathrm{mg}$ tissue was homogenized in $1 \mathrm{ml}$ of $1 \times$ phosphate-buffered saline PBS and stored at $-20^{\circ} \mathrm{C}$ overnight. The homogenates were centrifuged at 3000 r.p.m for $15 \mathrm{~min}$. Supernatants were used to evaluate malondialdehyde (MDA), glutathione (GSH), and catalase (CAT).

Estimation of level of MDA according to Ohkawa et al. [30], GSH concentrations were estimated according to Beutler et al. [31], and the method of Aebi [32] was used to determine the CAT activity in liver and brain tissues homogenates of both mother and fetus of all groups.

\section{Histopathological preparation}

Parts of maternal and fetal tissues (liver, kidney, brain, and placenta) of different groups were fixed in 10\% neutral buffered formalin then stored in $70 \%$ alcohol for a general histological preparation. Maternal and fetal tissues were dehydrated in ascending grades of ethyl alcohol, cleared in terpineol and embedded in paraffin wax. Serial transverse sections five microns thick of different tissues were cut mounted and stained with hematoxylin and eosin for general histological studies [33]. Histological changes were investigated under light microscope at magnification $400 \times$

\section{Statistical analysis}

Data were represented as mean \pm standard error (SE). Statistical analysis of data was performed using GraphPad Prism 5. Data were analyzed for statistical significance by the one-way analysis of variance followed by Tukey's multiple comparison test. The data at * $p<0.05$ were considered statistically significant.

\section{RESULTS}

\section{Teratological examinations}

Pregnancy outcome in the different groups was summarized in Table 1. Pregnant rats administered with NiO-NPs revealed a significant decrease in uterine weight, body weight gain, the average weight of placenta, the number corpora lutea, implantation sites, and the number of live fetuses when compared to the control group. Furthermore, there was a high pre/postimplantation loss/litter in NiO-NPs administered rats compared to the control. On the other hand, non-significant decrease was observed in postimplantation loss/litter and number of live fetuses of low dose of NiO-NPs when compared to the control $(\mathrm{p}<0.05)$.

The uterus of control pregnant rats on day 19 of gestation showed normal distribution of the implanted fetuses in the two horns (Fig. 1a). The uterus of pregnant rats received different doses of NiO-NPs, revealed asymmetrical distribution of fetuses in the two uteri horns, and early resorbed fetuses in one uterine horn (Fig. 1b and c).

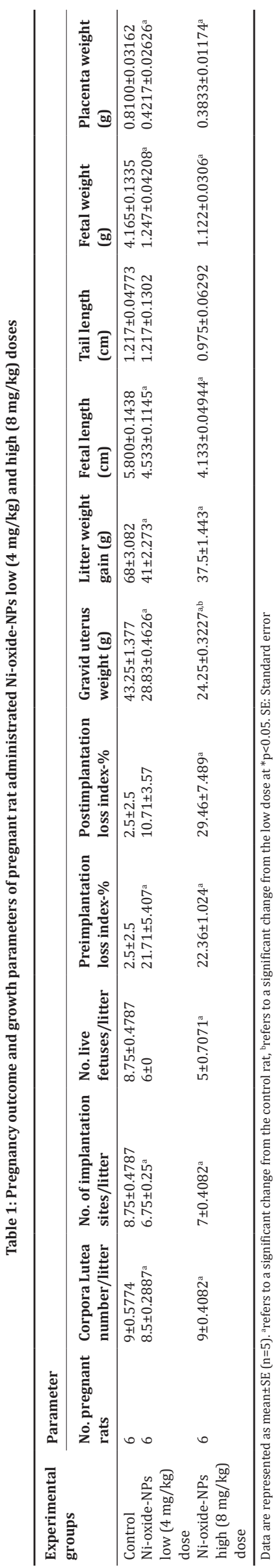


None of the animals in the groups which received NiO-NPs or control group gave dead fetuses. The morphological examination of the fetuses showed that NiO-NPs caused growth retardation represented by a decrease in fetal body weight, body length and tail length (Table 1). There was a significant $(\mathrm{p}<0.05)$ reduction in fetal body weight, fetal body length in the two different groups received NiO-NPs when compared with the control group.

The fetus from control pregnant rats appeared with normal shape, correct weight, and length (Fig. 2a). The gross pathology of fetuses per dam was represented in (Fig. $2 \mathrm{~b}$ and d). The most observed anomalies were microcephaly, short snout, shortness in forelimb, and club foot (Fig. 2b), umbilical hernia, protruding tongue, kinky tail, and two Fetuses with fused two placentas (Fig. 2c and d).
The skeletal examination of fetuses from control pregnant rats appeared with normal chondrification and ossification processes in all parts of the skeleton (Fig. 3a $\mathrm{a}_{1}-\mathrm{e}_{1}$ ). Skeletal abnormality of fetuses from dams which received the two different doses of NiO-NPs included a lack in the ossification of dorsal bones of skull (Fig. $3 \mathrm{a}_{2}$ ) and also completely absence of the ossification of all bones of skull (Fig. $3 \mathrm{a}_{3}$ ). Unconnected sternal rib, last sternbrae is non-ossified (Fig. $3 b_{2}$ ), and all sternbrae are non-ossified (Fig. $3 \mathrm{~b}_{3}$ ). Abnormal $13^{\text {th }}$ ribs was observed (Fig. 3c $\mathrm{c}_{2}$ ). Nonossified fibula, radius, metacarpals, and bones of the phalanges, Fused $9^{\text {th }}$ and $10^{\text {th }}$ caudal vertebra, absence of ulnare bone, and also curved ulnare bone were observed (Figs. $3 \mathrm{~d}_{2}-3 \mathrm{e}_{3}$ ).

\section{Comet assay}

NiO-NPs low $(4 \mathrm{mg} / \mathrm{kg})$ and high $(8 \mathrm{mg} / \mathrm{kg})$ doses significantly increased the \% DNA damage, tail length and tail moment
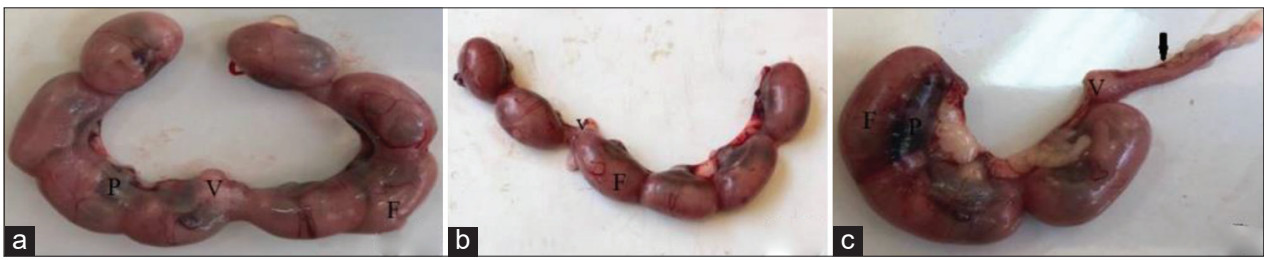

Fig. 1: Photographs of uterus of pregnant rat at the $19^{\text {th }}$ day of gestation. Control (a), low $(4 \mathrm{mg} / \mathrm{kg})$ dose Ni-oxide-NPs (b), and high (8 $\mathrm{mg} / \mathrm{kg}$ ) dose Ni-oxide-NPs (c). Normal distribution of fetuses in the two uterine horns (a). Two fetuses were observed in one uterine horn (b). Pinpoint hemorrhagic implantation sites (early resorption) (arrow) were observed in one uterine horn (c). $F=$ fetus, $v=v a g i n a$, $P=$ placenta

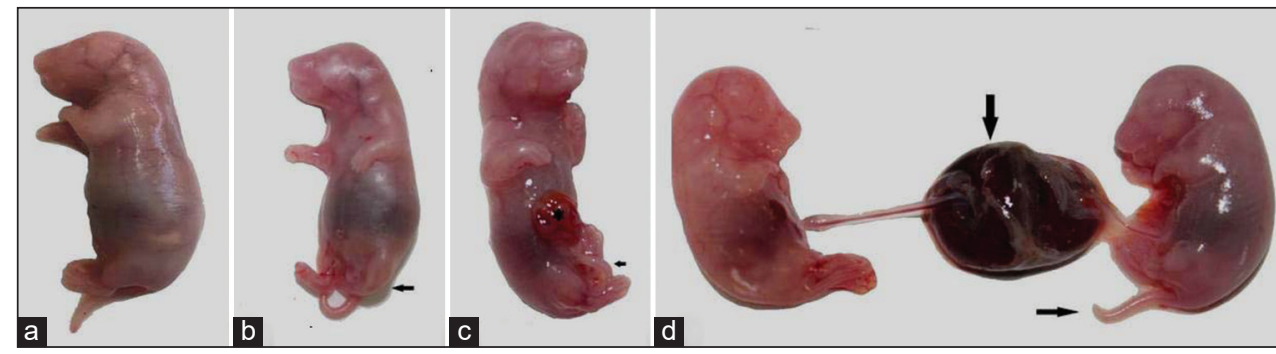

Fig. 2: Photographs of fetuses at $19^{\text {th }}$ day of gestation. Control, normal fetus (a), fetuses maternally administered with two different doses of NiO-NPs (b-d), showing fetus with microcephaly, short snout, shortness in forelimb and club foot (b), fetus with umbilical hernia, and kinky tail (c), two fetuses with fused two placentas (d)

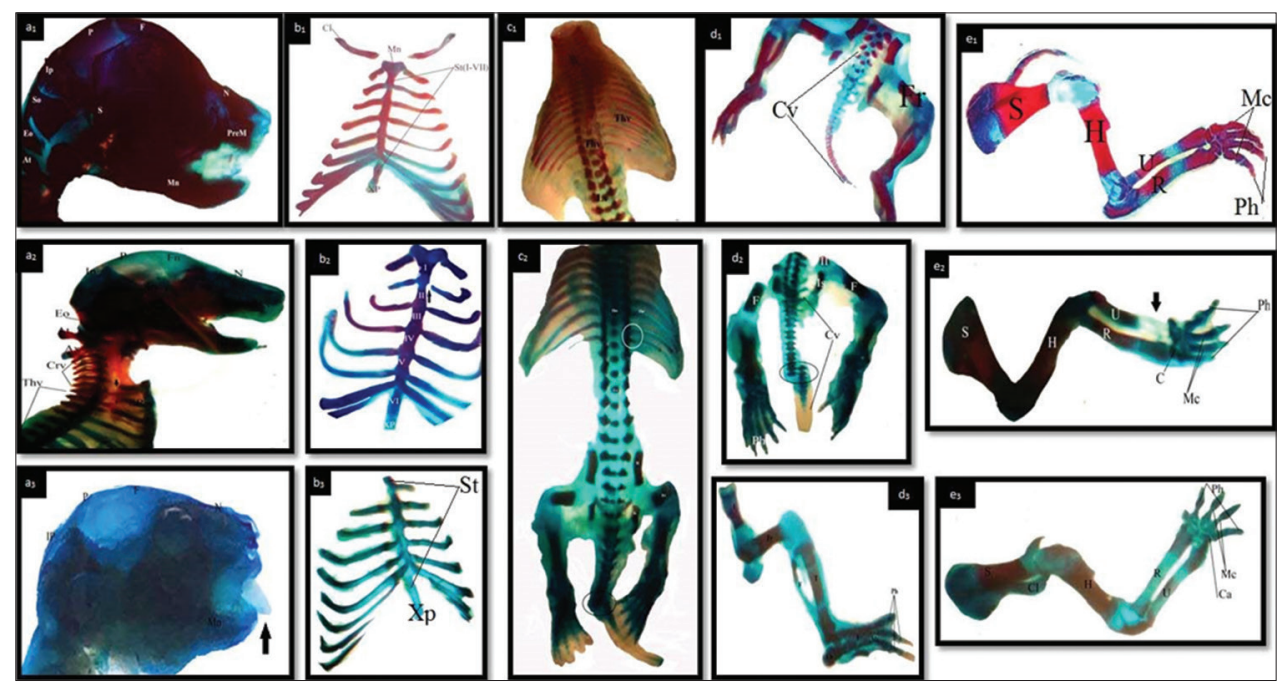

Fig. 3: Photographs of skeleton of fetuses at $19^{\text {th }}$ day of gestation. Control $\left(a_{1}-e_{1}\right)$, fetuses maternally administered with two different doses of nickel oxide nanoparticle $\left(a_{2}-e_{3}\right)$, showing lack in the ossification of dorsal bones of skull $\left(a_{2}\right)$ completely absence of the ossification of all bones of skull, protruding tongue (arrow) $\left(a_{3}\right)$. Unconnected sternal rib $\left(b_{2}\right)$ and all sternbrae are non- ossified $\left(b_{3}\right)$. Abnormal $13^{\text {th }}$ ribs (white circle), abnormal caudal vertebra (CV) (black circle) $\left(\mathrm{c}_{2}\right) .9^{\text {th }}$ and $10^{\text {Th }}$ caudal vertebra are fused (black circle), fibula, and bones of the phalanges, were non-ossified $\left(d_{2}-d_{3}\right)$. Absence of ulnare bone (arrow) and curved ulnare bone $\left(e_{2}-e_{3}\right)$ 
(parameters of comet assay) in maternal and fetal liver, and brain tissues in comparison to control group, as shown in Table 2 and Fig. $4 \mathrm{a}_{1}-\mathrm{b}_{4}$. The high-dose administration shows a significant increase of DNA fragmentation \% in comparison to the low dose NiO-NPs in the examined tissues.

Effect of NiO-NPs on oxidative stress in the liver and brain tissues Pregnant rats administrated with NiO-NPs low $(4 \mathrm{mg} / \mathrm{kg})$ and high $(8 \mathrm{mg} / \mathrm{kg}$ ) doses revealed a perturbation in the redox status in the fetal, maternal liver, and brain homogenates as indicated by the marked elevation $(\mathrm{p}<0.05)$ of MDA. The increment of these oxidants was correlated with a decrease in GSH content and CAT activities, as compared to control rat. The high-dose administration shows a significant increase of MDA and decrease in GSH content and CAT activities in comparison to the low dose NiO-NPs in the examined tissues except GSH content in fetal brain as shown in Table 3.

\section{Histopathological studies}

Placenta

Histologically, the placenta of control rats revealed the normal organization of different zones of the labyrinth zone, the basal zone, the decidua, and the metrial glands. Three types of differentiated cells: Spongiotrophoblasts, trophoblastic giant cells, and glycogen cells are the constituents of basal zone. The trophoblastic giant cell layer located below the spongiotrophoblasts. The multiple small cell masses of glycogen cells develop into glycogen cell islands. In the labyrinth zone, there are three layers of trophoblasts, separating the maternal blood spaces from the fetal blood vessels, the outer trophectoderm, (cytotrophoblasts with a microvillous surface), and the two syncytiotrophoblasts layers under the trophectoderm. Normal appearance of blood vessels was observed. The mesometrial decidual cells are the constituents of the decidua layer (Fig. $5 a_{1}, a_{2}$ ). The placenta of rats administrated with NiO-NPs revealed cystic degeneration in glycogen cells. Numerous apoptotic spongiotrophoblast cells were scattered, hemorrhagic areas and cysts in between the spongiotrophoblast cells of the basal zone (Fig. $5 b_{1}, c_{1}$ ). In the labyrinth zone, degeneration and necrosis of the trophoblasts, disruption of the thickness of trophoblastic septa with a deposition of calcium and fibrin. Additionally, degeneration of the fetal blood vessels and dilation in maternal sinusoids were seen (Fig. $5 b_{2}, c_{2}$ ).

\section{Liver}

\section{Liver of pregnant rats}

The microscopic examination of control pregnant rats liver revealed the normal histological structure of hepatic lobules from central vein and concentrically arranged hepatic cords (Fig. 6a). In contrary, examination of livers of NiO-NPs administrated rats revealed marked tissue alterations, fatty degeneration, cytoplasmic vacuolization of hepatocytes, dilated, and congested central vein with detached epithelium and some hepatocytes are necrotic hepatocytes. The nuclei of these cells are either pyknotized or karyolysed. In addition, fetuses exposed to the higher dose of NiO-NPs-induced focal hepatic necrosis associated with lymphatic infiltration and congested sinusoids, dilated portal vein (Fig. 6c and d),

\section{Liver of fetuses}

The microscopic examination of control liver of fetus revealed normal histological features. It consisted of cords of polyhedral hepatocytes with acidophilic cytoplasm. The hepatocytes were seen radiating from the central vein to the periphery of the hepatic lobule and alternating with blood sinusoids. The liver was permeated by rare megakaryocytes and conserved sinusoid capillaries (Fig. 7a). Fetuses maternally administered with NiO-NPs showed dilated, congested central vein with detached epithelium, necrotic areas and numerous vacuoles including fatty degeneration (Fig. 7b). In addition, fetuses exposed to the higher dose of NiO-NPs induced hepatocytes necrotic changes in the form of pale vacuolated cytoplasm and small dense pyknotic nuclei

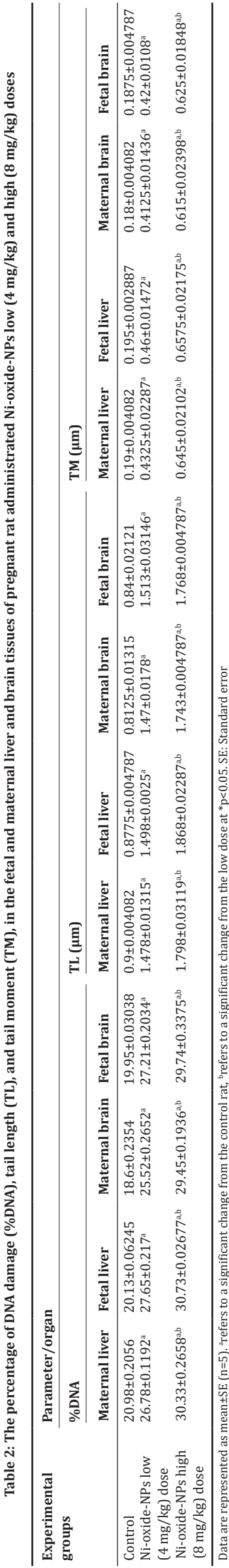




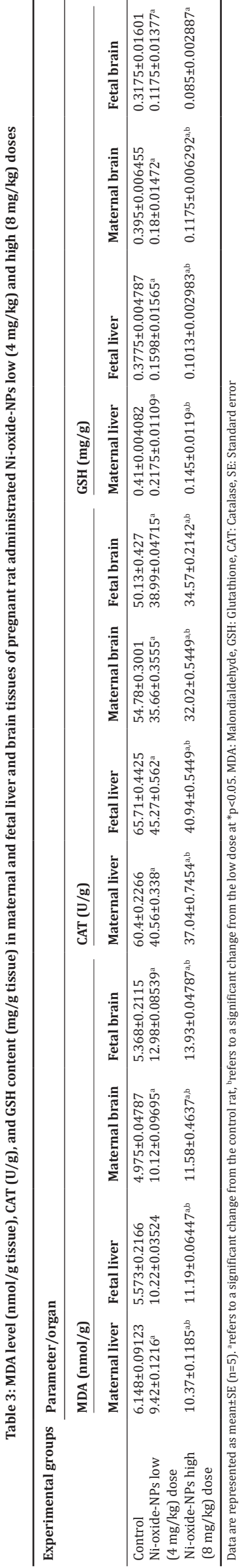

characterized by condensed chromatin and many megakaryocytes (Fig. 7c).

\section{Kidney}

Kidney of pregnant rats

The renal cortex of the control mothers displayed showed normal histological structure (Fig. 8a). Microscopic examination of the kidney of NiO-NPs administrated rats revealed marked tissue alterations, Hemosiderin deposits appeared as brown pigments in the renal tubules, congested, vacuolated glomeruli, hemorrhage in between the tubules and dilated, congested renal blood vessels (Fig. 8b). In addition, fetuses exposed to the higher dose of $\mathrm{NiO}-\mathrm{NPs}$ induced degenerative, vacuolation of glomeruli, and vacuolar degeneration and marked necrosis in tubules containing cytoplasmic vacuoles and pyknotic nuclei (Fig. 8c).

\section{Kidney of fetuses}

The kidney of fetus of control group showed normal histological structure (Fig. 9a). Meanwhile sections of kidney of fetuses maternally administrated with NiO-NPs revealed some histological changes such as severe degeneration of glomeruli showing shrinkage along with disrupted proximal and distal convoluted tubules, increased periglomerular space and the lining cells of the proximal and distal convoluted tubules exhibited degenerative changes, and their nuclei were pyknotized or karyolysed and hemorrhage in between the tubules and glomeruli (Fig. 9b). In addition, fetuses exposed to the higher dose of NiO-NPs induced multifocal areas of renal tubular necrosis, shrunken glomeruli (Fig. 9c).

\section{Brain}

Brain of pregnant rats

Microscopic examination of the H\&E stained sections of the cerebral cortex of the control group revealed normal organization (Fig. 10a). The gray matter was formed of six layers from outside inward. The common cells inside these layers are the neurons especially pyramidal and granule cells in addition to neuroglial cells. The background pink stained neuropil was a mat of neuronal and glial cell processes. Microscopic examination of the cerebral cortex of NiO-NPs administrated rats revealed marked tissue alterations, the pyramidal and granule cells lost their processes, irregular in shape, appeared as pyknotic neurons, their nuclei are deeply stained. In addition, vacuolization of the neuropil, dilated and congested blood vessels, and perineural spaces surrounded pyramidal and granule cells were observed (Fig. 10b and c). The severity of those histological alterations was dose dependent.

Microscopic examination of the H\&E stained sections of the cerebellar cortex of the control group revealed normal organization (Fig. 11a). The gray matter of the cerebellar cortex arranged regularly in three layers; outer molecular layer, middle Purkinje cell layer, and inner granular cell layer. Microscopic examination of the cerebellar cortex of NiO-NPs administrated rats revealed marked tissue alterations, the Purkinje cells had dark stained nuclei with eosinophilic cytoplasm and a lot of them are lost leaving empty spaces, vacuolated areas were seen in the molecular layer, granular layer revealed cell population reduction, shrunken cells (pyknotic nuclei), and vacuolated areas were seen in it (Fig. 11b and c). The severity of those histological alterations was dose dependent.

\section{Brain of fetuses}

The microscopic examination of cerebral cortex of control fetuses revealed the normal organization and distribution of the neurons in different zones of cerebral cortex; the cortical zone, the intermediate (migratory) zone and the ventricular (proliferative) zone (Fig. 12a). Fetuses maternally administrated with NiO-NPs revealed the appearance of hyperchromatic, condensed nuclei of apoptotic neuronal or glial cells. In addition, reduction in cell population, vacuolization of the neuropil, and dilated and congested blood vessels were observed in different zones (Figs. 12b and c). The severity of those histological alterations was dose dependent. 


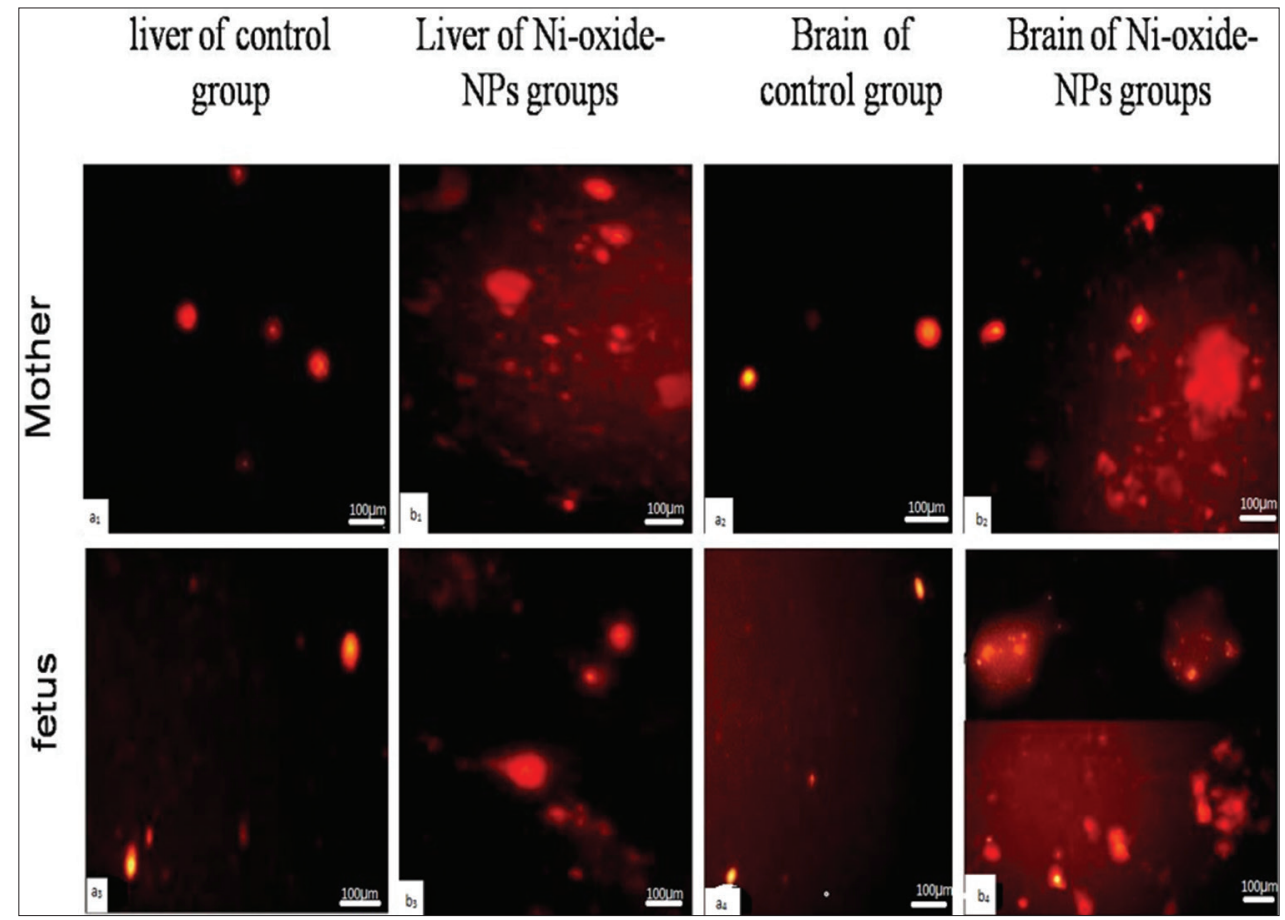

Fig. 4: Photomicrographs of comet assay showing $\left(a_{1-4}\right)$ typical nuclei of undamaged liver and brain cells of control group; $\left(b_{1-4}\right)$ DNA damage observed as comets in Ni-oxide-NPs low $(4 \mathrm{mg} / \mathrm{kg})$ and high $(8 \mathrm{mg} / \mathrm{kg})$ groups

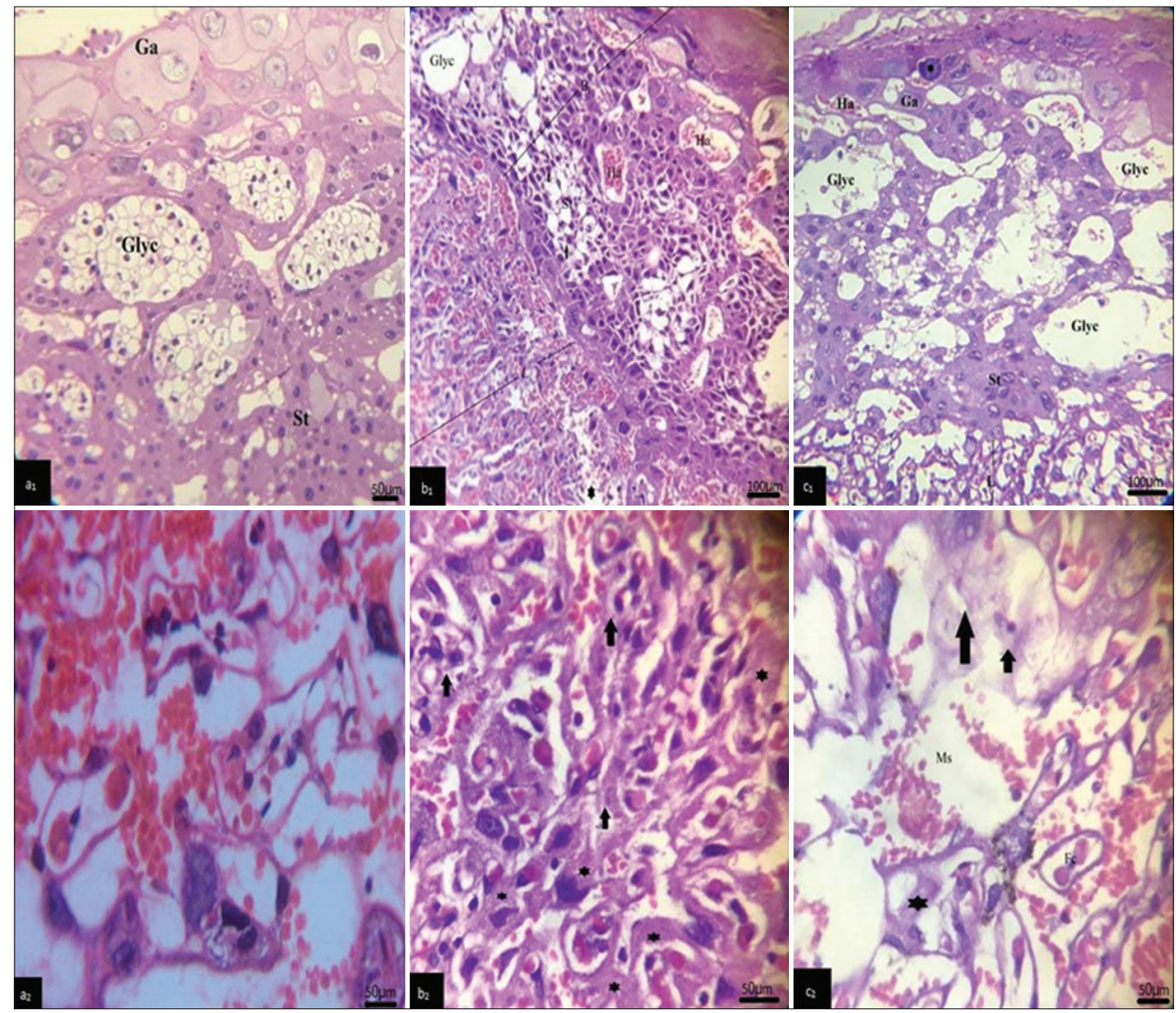

Fig. 5: Photomicrographs of cross-sections passing through the placenta of pregnant rats. Control $\left(\mathrm{a}_{1}, \mathrm{a}_{2}\right)$ showing normal organization of different zones of the basal zone (B) and the labyrinth zone (L). Low $(4 \mathrm{mg} / \mathrm{kg})$ dose Ni-oxide-NPs $\left(\mathrm{b}_{1}, \mathrm{~b}_{2}\right)$ showing giant cell (Ga), hemorrhagic cysts (Ha), trophoblast septa (T) and deposition of fibrin (asterisk), and pyknotic cell (arrows). High (8 mg/kg) dose Ni-oxide-NPs $\left(c_{1}, c_{2}\right)$ showing cystic degeneration of glycogen cells (Gly c), degeneration and necrosis of spongiotrophoblast (St) and trophoblasts (arrows), irregular dilatation of maternal sinusoids (MS) 

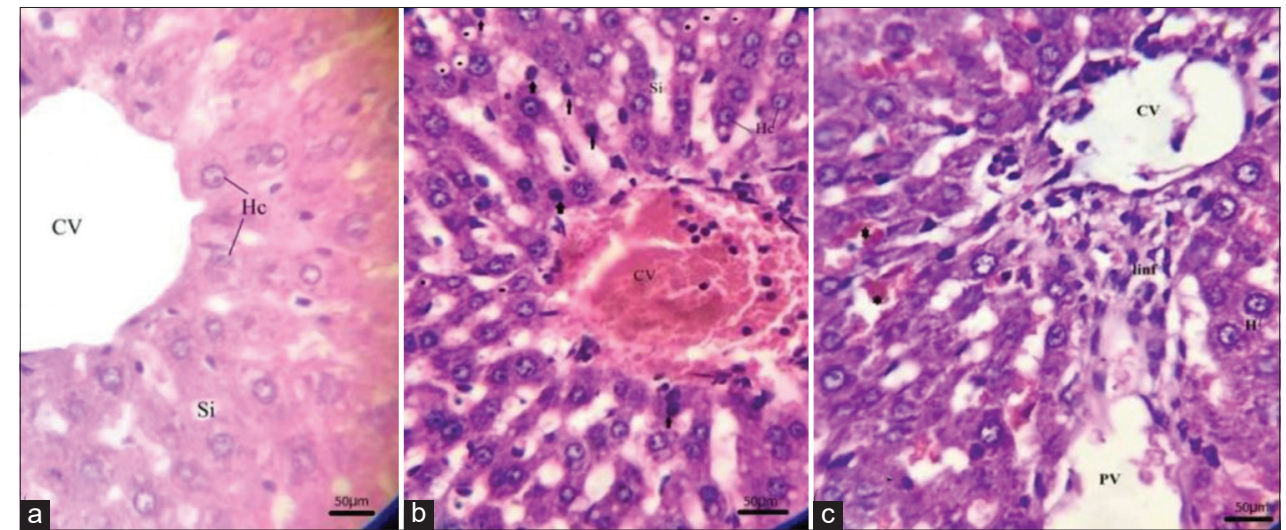

Fig. 6: Photomicrographs of cross-sections passing through the liver of pregnant rats. Control (a) showing normal architecture of maternal liver, low (4 mg/kg) dose Ni-oxide-NPs (b) showing hepatocytes (HC) exhibit fatty degeneration (asterisk), congested central vein (CV).,

Pyknotic hepatocyte, (arrows) and high $(8 \mathrm{mg} / \mathrm{kg})$ dose Ni-oxide-NPs (c) showing focal hepatic necrosis associated with lymphatic infiltration (Linf), blood sinusoids (Si) (asterisk) and dilated portal vein (PV)

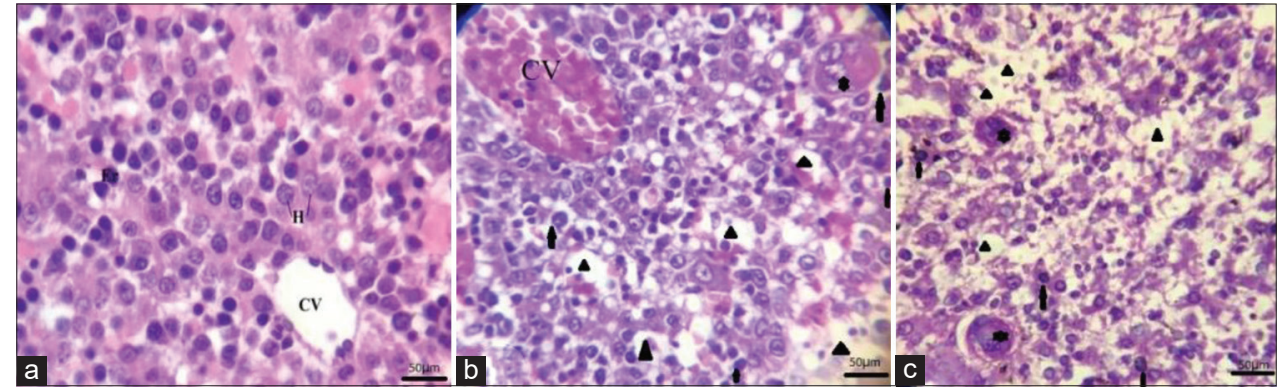

Fig. 7: Photomicrographs of cross-sections passing through the liver of rat fetuses. Control (a) showing normal architecture of fetal liver, low (4 $\mathrm{mg} / \mathrm{kg}$ ) dose Ni-oxide-NPs (b) showing megakaryocytes (asterisk), congested central vein (CV) with detached epithelium. High (8 mg/kg) dose Ni-oxide-NPs (c) showing pyknotic nuclei (arrows), hepatocytes necrotic changes in the form of pale vacuolated cytoplasm (headarrows).
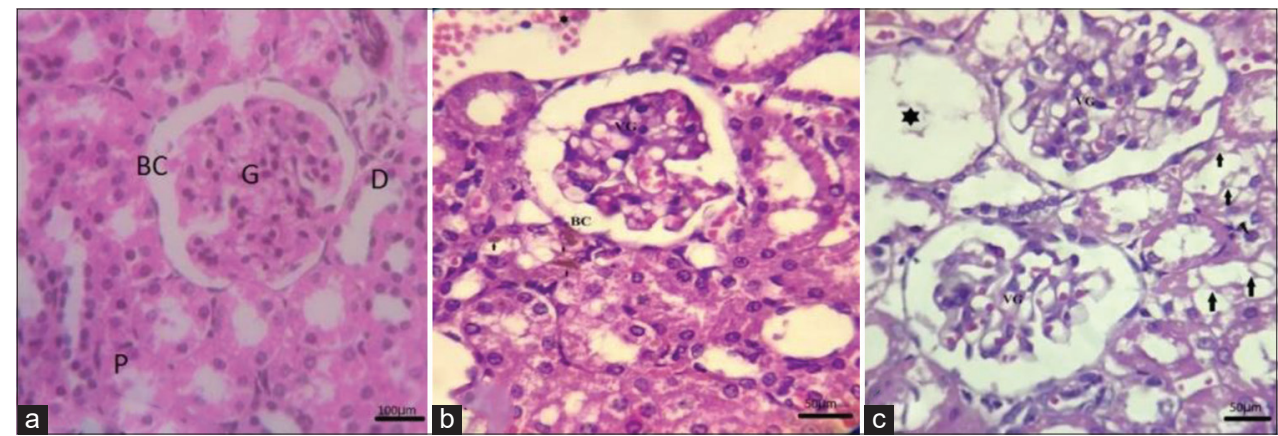

Fig. 8: Photomicrographs of cross-sections passing through the kidney of pregnant rats. Control (a) showing normal organization of maternal kidney, low $(4 \mathrm{mg} / \mathrm{kg}$ ) dose Ni-oxide-NPs (b) showing hemosiderin deposits (arrows) were demonstrated as brown pigments in the renal tubules, dilated, congested renal blood vessels (small asterisk), and high (8 mg/kg) dose Ni-oxide-NPs (c) showing degenerative (big asterisk) and vacuolation of glomeruli (VG), vacuolar degeneration and marked necrosis in tubules containing cytoplasmic vacuoles and pyknotic nuclei (arrows). The renal glomeruli (G), the glomerular capsule (BC), the proximal (P), and distal (D) convoluted tubules

\section{DISCUSSION}

Metallic NiNPs have extensive applications in nearly all manufacturing fields [34]. The workers occupationally exposed to the NiONPs through environmental and occupational settings. During manufacture, NPs may accidentally get ingested through hands [35,36]. After absorption through gastrointestinal tract, NiO NPs may penetrate the blood stream run across the liver followed by other visceral organs [37]. Despite the widespread of NiO NPs and their benefits in all fields, they have many negative effects on human life, especially expectant mothers and their fetus. To my knowledge, the present investigation is the first study confirmed the maternal and developmental toxicity in rats of NiO NPs administration during pregnancy.
The present study revealed that NiO NPs administration induced a significant reduction in uterine weight, mother weight gain, the average weight of placenta, the number corpora lutea, implantation sites, and the number of live fetuses. Furthermore, there was a high pre/postimplantation and a significant reduction in the growth parameters of fetuses; these findings are in agreement with the findings of some previous studies showed that potential fetal toxicity, such as premature birth, decreased birth weight, and small size for gestational age and fetal malformation due to NPs exposure [38-41]. The body weight and organ weight are the sensitive indicators of potentially toxic chemicals as reported in the general reproductive toxicity studies by Andersen et al., Bailey et al., Chung et al. [42-44]. 


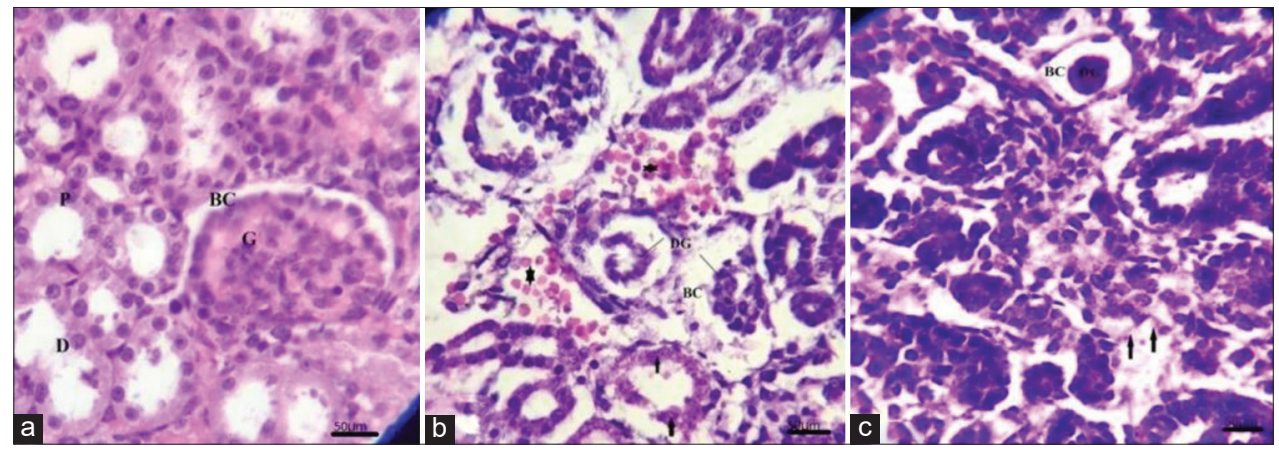

Fig. 9: Photomicrographs of cross-sections passing through the kidney of rat fetuses. Control (a) showing normal organization of fetal kidney, low (4 mg/kg) dose Ni-oxide-NPs (b) showing severe degeneration of glomeruli (DG). Moreover, the lining cells of the proximal and distal convoluted tubules exhibited degenerative changes (arrows), and hemorrhage in between the tubules and glomeruli (asterisk), and high

$(8 \mathrm{mg} / \mathrm{kg}$ ) dose Ni-oxide-NPs (c) showing multifocal areas of renal tubular necrosis (arrows), degenerated shrunken glomeruli (DG)

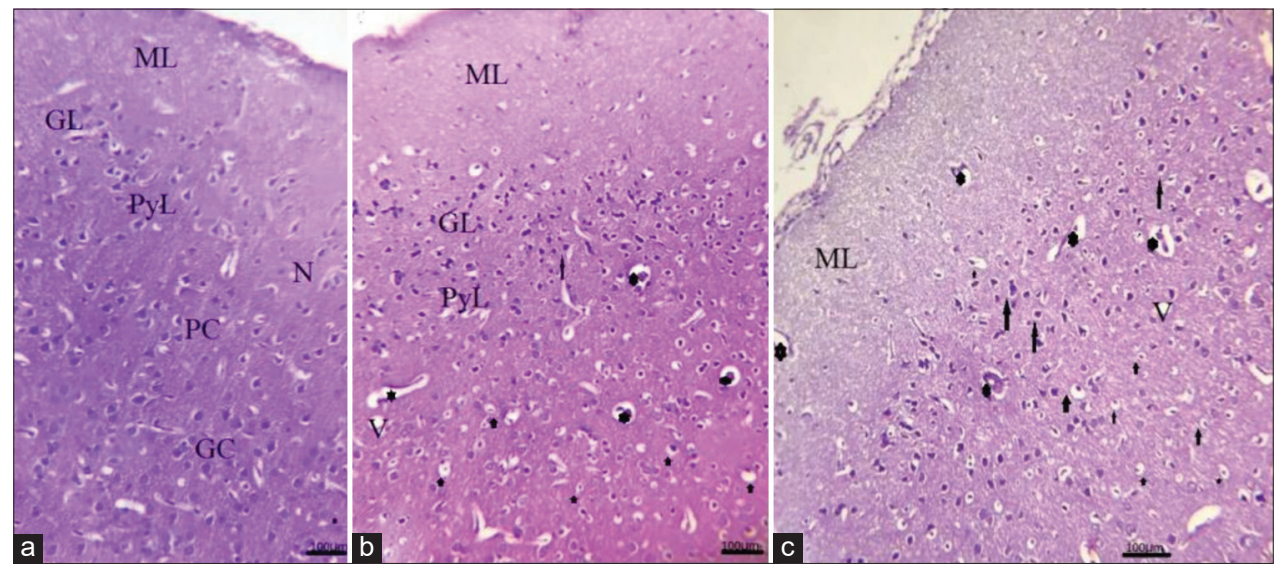

Fig. 10: Photomicrographs of cross-sections passing through the cerebral cortex of pregnant rats. Control (a) showing normal organization of maternal brain, low (4 mg/kg) dose Ni-oxide-NPs (b), and high $(8 \mathrm{mg} / \mathrm{kg})$ dose Ni-oxide-NPs (c) showing dark stained nuclei of pyknotic neuron (long arrow), perineural spaces(short arrows), vaculatization of neuropil (V), and dilated congested blood vessels (asterisk). The molecular layer (ML), granular layer (GL), pyramidal layer (PL), pyramidal cells (PC), granule cells (GC), and neuroglial cell (N)

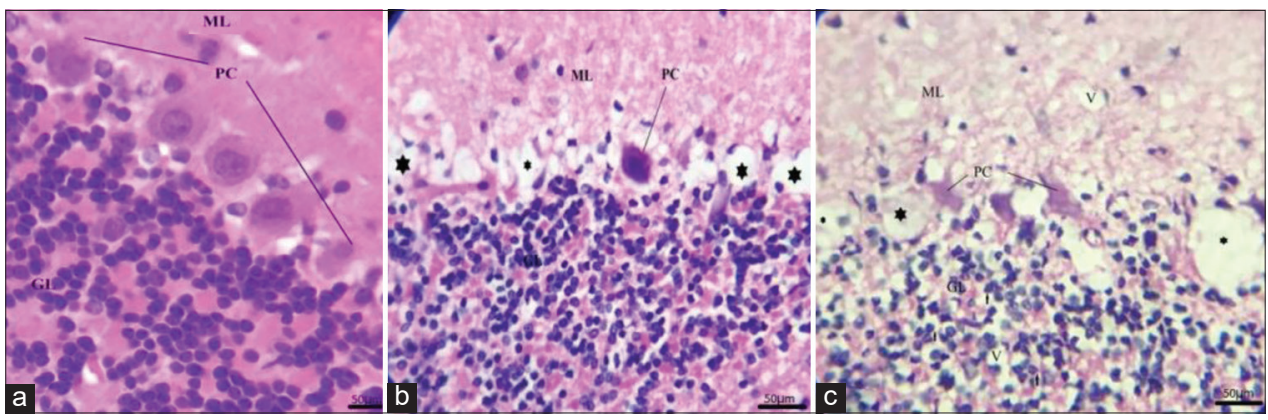

Fig. 11: Photomicrographs of cross-sections passing through the cerebellar cortex of pregnant rats. Control (a) showing normal organization of layers of the cerebellum: The molecular layer (ML), Purkinje layer having large flask-shaped Purkinje cells (PC), and granular layer (GL). Low (4 mg/kg) dose Ni-oxide-NPs (b) and high (8 mg/kg) dose Ni-oxide-NPs (c), Purkinje cells (PC) with an eosinophilic cytoplasm and a lot of them are lost leaving empty spaces (asterisk), vacuolated areas in molecular layer and granular layer (V), pyknotic nuclei (arrows).

The transplacental transfer of silica (Si) $(70 \mathrm{~nm})$ and TiO2 NPs (35 nm) and attachment of the particles to the placental trophoblasts following an intravenous injection, and they revealed that the uterine weight reduction, high fetal resorption rate, and smaller fetuses due to the placental dysfunction [38].

Different external and skeletal malformations such as short or absent tails, fusion of the ribs, or vertebral bodies in all of the multi-wall carbon nanotube (MWCNT) intraperitoneally injected groups [45].
The most observed that external and skeletal anomalies in the $\mathrm{NiO}$ NPs administrated groups were microcephaly, short snout, shortness in forelimb and club foot, umbilical hernia, protruding tongue, kinky tail, two fetuses with fused two placentas, a lack and completely absence in the ossification of dorsal bones of skull, unconnected sternal rib, last or all sternbrae are non-ossified, abnormal $13^{\text {th }}$ ribs $9^{\text {th }}$ and $10^{\text {Th }}$ caudal vertebra are fused, fibula, radius, metacarpals, and bones of the phalanges, were non-ossified, absence of ulnare bone and also curved ulnare bone. These findings are in agreement with the findings of $[26,45]$. 


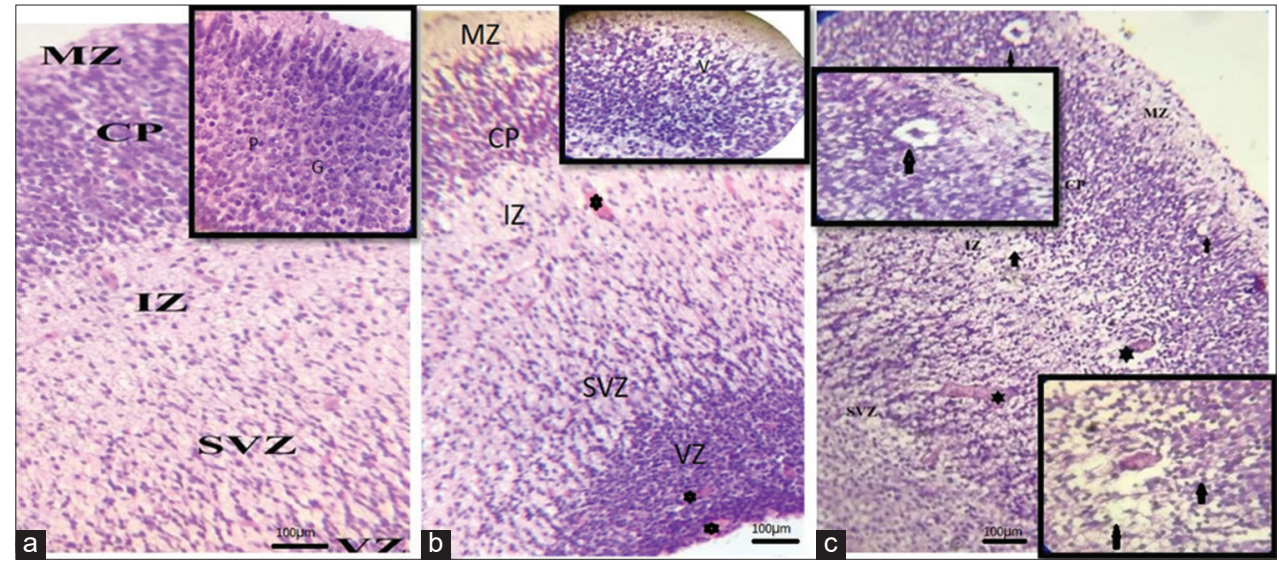

Fig. 12: Photomicrographs of cross-sections passing through the cerebral cortex of rat fetuses. Control (a) showing normal organization of fetal cortical layers: MZ: Marginal zone; CP: Cortical plate; IZ: Intermediate zone; SVZ: Subventricular zone; VZ: Ventricular zone.

(c) Different nerve cells in the cerebral cortex. G: Granule cells, P: pyramidal cells, low (4 mg/kg) dose Ni-oxide-NPs (b), and high $(8 \mathrm{mg} / \mathrm{kg}$ ) dose Ni-oxide-NPs (c), reduction in cell population, vacuolization of the neuropil (V), pyknotic nuclei of nerve cells (arrows), and dilated and congested blood vessels (asterisk) were observed in different zones

Due to the tiny particle size, increased surface area and reactivity of $\mathrm{NiO} \mathrm{NPs}$, it could probably release more $\mathrm{Ni}$ ions in the liquid milieu for intracellular uptake and mobilization, thus exerting stronger biodistribution [46].

In vitro study revealed that osteoblasts exposed to $\mathrm{Ni}^{+2}$ showed significant decreases in alkaline phosphatase activity [47]. Osteoblasts cultured with $\mathrm{NiCl}_{2}$-induced severe osteoblast apoptosis [48] and dysfunction [49]. Administration of $\mathrm{Ni}^{+2}$ in rats induced a decreased number of primary and secondary osteons [50].

In conformity with former work [47-50], the absence or reduction of ossification in different bones of skeleton may be attributed to alteration in calcium metabolism or decrease in calcium and magnesium ion levels as well as alteration in calcitonin level in the growing fetus, thereby causing retardation in bone development.

Many studies reported that several nanoparticles can readily pass through the placental barrier [38,51-55].

The NPs can be transported to organs related to pregnancy and fetal development and may be taken up by placental cells and interfere indirectly with fetal development by inducing oxidative stress and inflammation at that site [56].

The oxidized MWCNTs can cross the placenta and induce placental dysfunction, causing a delay in fetal growth, and accumulating in the liver, lungs, and heart of fetus leading to fetal resorption [41].

The fetus may either be affected directly through transplacental transfer or indirectly through placental dysfunction [38] and by inflammation through the activated cytokines or other secondary messengers and/or oxidative stress in maternal organs [57].

The Ag-NPs exposure induced fetal cell dysfunction by ROS generation in the mother's body which penetrated the fetal blood circulation and activated ROS-mediated oxidative stress responses [58]

The normal function and structure of the placenta are the basis for the normal development of the fetus. Previous studies reported that placental dysfunction can restrict fetal growth and miscarriage [59]. In the present results, NiO NPs exposure revealed placental structure alterations, numerous apoptotic spongiotrophoblast cells were scattered, hemorrhagic areas, and cysts in between the spongiotrophoblast cells of the basal zone. This indicated that exposure to the NiO NPs may have damaged the normal structure of the placenta which may have affected the placental function in accordance with $[38,41]$.

The nano-NiO-induced liver toxicity may be associated with oxidative stress in rats [59]. The current work revealed that NiO NPs administration induces oxidative stress in liver and brain tissues of fetuses and pregnant rats. MDA levels were significantly increased while GSH level was significantly decreased in NiO NPs administered groups. The depletion of GSH and CAT in NiO NPs exposed rats combined with the increased level of MDA suggests that oxidative stress is the primary mechanism for toxicity of NiO NPs in maternal and fetal tissues as reported by Dumala et al., Saquib et al., Kannan et al., Wells et al., Yu et al. [20,22,57,58,60].

Particles which are $<100 \mathrm{~nm}$ are capable of entering cells and attach to macromolecules such as DNA and proteins leading to DNA damage [61].

Exposure to NiO NPs leads to bio-distribution of $\mathrm{Ni}$ in many organs of the body which is causing significant DNA damage in rats. This indicates that the accumulated $\mathrm{Ni}$ leads to potential genotoxicological impacts [20].

Some studies revealed that potential genotoxic impacts and severe DNA damage such as DNA deletions, DNA strand breaks, mutations, and oxidative DNA adducts due to the maternal exposure to NPs during gestation [62-64]

In conformity with former work [20,22,62-64], the comet data of the current work revealed significant DNA damage in NiO NPs administered groups in both fetal and maternal liver and brain tissues.

Our results are consistent with previous studies suggesting that genotoxicity of NiO NPs is attribute to the oxidative stress induced by excess ROS [60,65-67]. Nanoparticle-induced oxidative stress leads to DNA damage and apoptosis [68].

Some transfer of NiO NPs and penetration of nickel into the brain from the nasal mucous membrane along the olfactory pathway, causing damage to the corresponding structures of the brain after NiO NPs inhalation [69].

Previous animal studies highlight the potential vulnerability of the fetal brain to the toxicity of a variety of different types of NPs, in advance of the formation of a robust blood-brain barrier [70-72]. Brain of fetuses is affected easily by nano-sized materials than brain of adults due to the incomplete development of the blood-brain barrier of fetal brain 
[73]. The entry of TiO2 NPs $(<300 \mathrm{~nm})$ into the brain of the offspring of the subcutaneous injected pregnant mice, causing blood vessel stenosis in their hippocampus and cerebral cortex [52]. The NPs may cause neurotoxicity in the fetus by damaging the central nervous system after the maternal exposure to NPs [74-78].

The histological examination confirmed the prominent pathology in different tissues (placenta, liver, kidney, and brain) of pregnant rats and fetuses. These findings are in line with some recent in vivo studies revealed alterations in brain, liver, and kidney tissues [65], and in liver tissues [22]. We suggested that these findings might be attributed to the distribution of $\mathrm{NiO} \mathrm{NPs}$ and $\mathrm{Ni}$ content in all the body organs, NiO NPs could be translocated to other body sites through systemic circulation following oral exposure as reported by Saquib et al., Qi et al., Dumala et al., Yokota et al., Sugamata et al., Jackson et al. [22,41,65,70-72].

The solubilization of $\mathrm{Ni2}+$ from NiO-NPs plays an essential role in inducing toxicity in animal, invertebrate, cell line, and plant documented by many previous studies [79-82]. We suggested that these findings attributed to the dissolution of $\mathrm{Ni2}+$ from NiO-NPs under acidic condition of stomach as reported by Saquib et al. [22]. Ni2+ is involved in ROS generation and attributed for inducing high level of damage through direct oxidative damage by the production of $\mathrm{H}_{2} \mathrm{O}_{2}$ [83]. Hence, the toxicity and damage in the present study could attribute also to oxidative action of Ni2+released from NiO-NPs.

Ni NPs had reproductive toxicity by affecting hormone levels in female rats [18]. Consistent with the present results, it has been suggested that NiO NPs and $\mathrm{Ni2}+$ content exerts their actions directly on the developing embryo/fetus (crossing the placenta), as well as indirectly by altering the maternal hormonal balance as reported by Kong et al., Cempel and Janicka, Saini et al. $[18,84,85]$.

\section{CONCLUSION}

According to the current data, it could be concluded that the detrimental impacts of Nickel oxide nanoparticles ( $\mathrm{NiO} \mathrm{NPs}$ ) in dams and fetuses probably through its potential generation of reactive oxygen species. Further research is needed to elucidate mechanism of actions of $\mathrm{NiO}$ NP toxicity.

\section{AUTHORS' CONTRIBUTIONS}

The author did all the work, read, and approved the final manuscript.

\section{CONFLICTS OF INTEREST}

No potential conflicts of interest were reported by the author.

\section{FUNDING}

No research funding was available for this study.

\section{REFERENCES}

1. Long NV, Yang Y, Teranishi T, Thi CM, Cao Y, Nogami M. Biomedical applications of advanced multifunctional magnetic nanoparticles. J Nanosci Nanotechnol 2015:15:10091-107.

2. Räthel T, Mannell H, Pircher J, Gleich B, Pohl U, Krötz F. Magnetic stents retain nanoparticle-bound antirestenotic drugs transported by lipid microbubbles. Pharm Res 2012;29:1295-307.

3. Yuan YQ, Yuan FL, Li FL, Hao ZM, Guo J, Young DJ, et al. A cuboidal [Ni4O4] cluster as a precursor for recyclable, carbon-supported nickel nanoparticle reduction catalysts. Dalton Trans 2017;46:7154-58.

4. Melkhanova S, Haluska M, Hubner R, Kunze T, Keller A, Abrasonis G, et al. Carbon: Nickel nanocomposite templates-predefined stable catalysts for diameter-controlled growth of single-walled carbon nanotubes. Nanoscale 2016;8:14888-97.

5. Hyeon T. Chemical synthesis of magnetic nanoparticles. Chem Commun (Camb) 2003;8:927-34

6. Ates M, Demir V, Arslan Z, Camas M, Celik F. Toxicity of engineered nickel oxide and cobalt oxide nanoparticles to Artemia salina in seawater. Water Air Soil Pollut 2016;227:70.

7. Mishra S, Yogi P, Sagdeo PR, Kumar R. Mesoporous nickel oxide $(\mathrm{NiO})$ nanopetals for ultrasensitive glucose sensing. Nanoscale Res Lett 2018;13:16.

8. Parsaee Z. Synthesis of novel amperometric urea-sensor using hybrid synthesized NiO-NPs/GO modified GCE in aqueous solution of cetrimonium bromide. Ultrason Sonochem 2018;44:120-8.

9. Shen Y, Lua AC, Xi J, Qiu X. Ternary platinum-copper-nickel nanoparticles anchored to hierarchical carbon supports as freestanding hydrogen evolution electrodes. ACS Appl Mater Interfaces 2016;8:3464-72.

10. Talapin DV, Lee JS, Kovalenko MV, Shevchenko EV. Prospects of colloidal nanocrystals for electronic and optoelectronic applications. Chem Rev 2010;110:389-458.

11. Fratila RM, Rivera-Fernández S, de la Fuente JM. Shape matters: Synthesis and biomedical applications of high aspect ratio magnetic nanomaterials. Nanoscale 2015;7:8233-60.

12. Sousa CA, Soares HM, Soares EV. Nickel oxide $(\mathrm{NiO})$ nanoparticles disturb physiology and induce cell death in the yeast Saccharomyces cerevisiae. Appl Microbiol Biotechnol 2018;102:2827-38.

13. Kang GS, Gillespie PA, Gunnison A, Moreira AL, Tchou-Wong KM, Chen LC. Long-term inhalation exposure to nickel nanoparticles exacerbated atherosclerosis in a susceptible mouse model. Environ Health Perspect 2011;119:176-81.

14. Glista-Baker EE, Taylor AJ, Sayers BC, Thompson EA, Bonner JC. Nickel nanoparticles cause exaggerated lung and airway remodeling in mice lacking the T-box transcription factor, TBX21 (T-bet). Part Fibre Toxicol 2014;11:7.

15. Liberda EN, Cuevas AK, Gillespie PA, Grunig G, Qu Q, Chen LC. Exposure to inhaled nickel nanoparticles causes a reduction in number and function of bone marrow endothelial progenitor cells. Inhal Toxicol 2010;22 Suppl 2:95-9

16. Phillips JI, Green FY, Davies JC, Murray J. Pulmonary and systemic toxicity following exposure to nickel nanoparticles. Am J Ind Med 2010;53:763-7.

17. Magaye R, Zhou Q, Bowman L, Zou B, Mao G, Xu J, et al. Metallic nickel nanoparticles may exhibit higher carcinogenic potential than fine particles in JB6 cells. PLoS One 2014;9:e92418.

18. Kong L, Tang M, Zhang T, Wang D, Hu K, Lu W, et al. Nickel nanoparticles exposure and reproductive toxicity in healthy adult rats. Int J Mol Sci 2014;15:21253-69.

19. Ispas C, Andreescu D, Patel A, Goia DV, Andreescu S, Wallace KN. Toxicity and developmental defects of different sizes and shape nickel nanoparticles in zebrafish. Environ Sci Technol 2009;43:6349-56.

20. Dumala N, Mangalampalli B, Chinde S, Kumari SI, Mahoob M, Rahman MF, et al. Genotoxicity study of nickel oxide nanoparticles in female Wistar rats after acute oral exposure. Mutagenesis 2017;32:417-27

21. Dumala N, Mangalampalli B, Kamal SS, Grover P. Biochemical alterations induced by nickel oxide nanoparticles in female Wistar albino rats after acute oral exposure. Biomarkers 2018;23:33-43.

22. Saquib Q, Attia SM, Ansari SM, Al-Salim A, Faisal M, Alatar AA, et al. p53, MAPKAPK-2 and caspases regulate nickel oxide nanoparticles induce cell death and cytogenetic anomalies in rats. Int J Biol Macromol 2017; 105:228-37.

23. Liu J, Feng X, Wei L, Chen L, Song B, Shao L. The toxicology of ionshedding zinc oxide nanoparticles. Crit Rev Toxicol 2016;46:348-84.

24. Zhou L, Zhuang W, Wang X, Yu K, Yang S, Xia S. Potential acute effects of suspended aluminum nitride (AIN) nanoparticles on soluble microbial products (SMP) of activated sludge. J Environ Sci 2017:57:284-92.

25. National Toxicology Program. Nickel compounds and metallic nickel. Rep Carcinog 2011;12:280-3. Available from: https://www.ntp.niehs. nih.gov/ntp/roc/content/profiles/nickel.pdf.

26. El Ghareeb AW, Hamdi H, El Bakry A, Abo Hmela H. Teratogenic effects of the titanium dioxide nanoparticles on the pregnant female rats and their off springs. Res J Pharm Biol Chem Sci 2015;6:510-23.

27. Young AD, Phipps DE, Astroff AB. Large-scale double-staining of rat fetal skeletons using Alizarin Red S and alcian blue. Teratology 2000;61:273-6

28. Nandhakumar S, Parasuraman S, Shanmugam MM, Rao KR, Chand P, Bhat BV. Evaluation of DNA damage using single-cell gel electrophoresis (Comet Assay). J Pharmacol Pharmacother 2011;2:107-11.

29. El-shorbagy HM, Hamdi H. Genotoxic and mutagenic studies of the antiepileptic drug levetiracetamin pregnant rats and their fetuses. Int J Pharm Pharm Sci 2015;8:82-8. 
30. Ohkawa H, Ohishi N, Yagi K. Assay for lipid peroxides in animal tissues by thiobarbituric acid reaction. Anal Biochem 1979;95:351-8.

31. Beutler E, Duron O, Kelly MB. Improved method for the determination of blood glutathione. J Lab Clin Med 1963;61:882-8.

32. Aebi H. Catalase in vitro. Methods Enzymol 1984;105:121-6.

33. Bancroft JD, Gamble M. Theory and Practice of Histological Techniques. $6^{\text {th }}$ ed. Edinburgh, UK: Churchill Livingstone; 2008.

34. Griffitt RJ, Luo J, Gao J, Bonzongo JC, Barber DS. Effects of particle composition and species on toxicity of metallic nanomaterials in aquatic organisms. Environ Toxicol Chem 2008;27:1972-8.

35. Singh SP, Kumari M, Kumari SI, Rahman MF, Mahboob M, Grover P. Toxicity assessment of manganese oxide micro and nanoparticles in Wistar rats after 28 days of repeated oral exposure. J Appl Toxicol 2013;33:1165-79.

36. Kumari M, Singh SP, Chinde S, Rahman MF, Mahboob M, Grover P. Toxicity study of cerium oxide nanoparticles in human neuroblastoma cells. Int J Toxicol 2014;33:86-97.

37. Schleh C, Semmler-Behnke M, Lipka J, Wenk A, Hirn S, Schäffler M, et al. Size and surface charge of gold nanoparticles determine absorption across intestinal barriers and accumulation in secondary target organs after oral administration. Nanotoxicology 2012;6:36-46

38. Yamashita K, Yoshioka Y, Higashisaka K, Mimura K, Morishita Y, Nozaki M, et al. Silica and titanium dioxide nanoparticles cause pregnancy complications in mice. Nat Nanotechnol 2011;6:321-8.

39. Shah PS, Balkhair T. Knowledge Synthesis Group on Determinants of Preterm/LBW Births. Air pollution and birth outcomes: A systematic review. Environ Int 2011;37:498-516.

40. Takeda K, Shinkai Y, Suzuki K, Yanagita S, Umezawa M, Yokota S, et al. Health effects of nanomaterials on next generation. Yakugaku Zasshi 2011;131:229-36.

41. Qi W, Bi J, Zhang X, Wang J, Wang J, Liu P, et al. Damaging effects of multi-walled carbon nanotubes on pregnant mice with different pregnancy times. Sci Rep 2014;4:4352.

42. Andersen H, Larsen S, Spliid H, Christensen ND. Multivariate statistical analysis of organ weights in toxicity studies. Toxicology 1999;136:67-77.

43. Bailey SA, Zidell RH, Perry RW. Relationships between organ weight and body/brain weight in the rat: What is the best analytical endpoint? Toxicol Pathol 2004;32:448-66.

44. Chung MK, Kim CY, Kim JC. Reproductive toxicity evaluation of a new camptothecin anticancer agent, CKD-602, in pregnant/lactating female rats and their offspring. Cancer Chemother Pharmacol 2007;59:383-95.

45. Fujitani T, Ohyama K, Hirose A, Nishimura T, Nakae D, Ogata A. Teratogenicity of multi-wall carbon nanotube (MWCNT) in ICR mice. J Toxicol Sci 2012;37:81-9.

46. Pietruska JR, Liu X, Smith A, McNeil K, Weston P, Zhitkovich A, et al. Bioavailability, intracellular mobilization of nickel, and HIF-1 $\alpha$ activation in human lung epithelial cells exposed to metallic nickel and nickel oxide nanoparticles. Toxicol Sci 2011;124:138-48.

47. Yamaguchi M, Ehara Y. Effect of essential trace metal on bone metabolism in the femoral-metaphyseal tissues of rats with skeletal unloading: Comparison with zinc-chelating dipeptide. Calcif Tissue Int 1996;59:27-32.

48. Gough JE, Downes S. Osteoblast cell death on methacrylate polymers involves apoptosis. J Biomed Mater Res 2001;57:497-505.

49. Kapanen A, Ilvesaro J, Danilov A, Ryhänen J, Lehenkari P, Tuukkanen J. Behaviour of nitinol in osteoblast-like ROS-17 cell cultures. Biomaterials 2002;23:645-50.

50. Chovancová H, Martiniaková M, Omelka R, Grosskopf $\mathrm{B}$, Toman R. Structural changes in femoral bone tissue of rats after intraperitoneal administration of nickel. Pol J Environ Stud 2011;20:1147-52.

51. Semmler-Behnke M, Fertsch S, Schmid O, Wenk A, Kreyling WG: Uptake of $1.4 \mathrm{~mm}$ Versus $18 \mathrm{~mm}$ Gold Particles by Secondary Target Organs is Size Dependent in Control and Pregnants Rats after Intertracheal or Intravenouz Application, Euro NanoforumNanotechnology in Industrial Applications; 2007. p. 102-4. Available from: https://www.ec.europa.eu/research/industrial technologies/pdf/ euronanoforum2007-proceedings_en.pdf.

52. Takeda K, Suzuki KI, Ishihara A, Kubo-Irie M, Fujimoto R, Tabata M, et al. Nanoparticles transferred from pregnant mice to their offspring can damage the genital and cranial nerve systems. J Health Sci 2009;55:95-102.

53. Chu M, Wu Q, Yang H, Yuan R, Hou S, Yang Y, et al. Transfer of quantum dots from pregnant mice to pups across the placental barrier. Small 2010;6:670-8

54. Sumner SC, Fennell TR, Snyder RW, Taylor GF, Lewin AH. Distribution of carbon-14 labeled $\mathrm{C} 60([14 \mathrm{C}] \mathrm{C} 60)$ in the pregnant and in the lactating dam and the effect of $\mathrm{C} 60$ exposure on the biochemical profile of urine. J Appl Toxicol 2010;30:354-60

55. Refuerzo JS, Godin B, Bishop K, Srinivasan S, Shah SK, Amra S, et al. Size of the nanovectors determines the transplacental passage in pregnancy: Study in rats. Am J Obstet Gynecol 2011;204:546.

56. Brohi RD, Wang L, Talpur HS, Wu D, Khan FA, Bhattarai D, et al. Toxicity of nanoparticles on the reproductive system in animal models: A review. Front Pharmacol 2017;8:606.

57. Kannan S, Misra DP, Dvonch JT, Krishnakumar A. Exposures to airborne particulate matter and adverse perinatal outcomes: A biologically plausible mechanistic framework for exploring potential effect modification by nutrition. Environ Health Perspect 2006;114:1636-42.

58. Wells PG, Bhuller Y, Chen CS, Jeng W, Kasapinovic S, Kennedy JC, et al. Molecular and biochemical mechanisms in teratogenesis involving reactive oxygen species. Toxicol Appl Pharmacol 2005;207:354-66.

59. Perez-Garcia V, Fineberg E, Wilson R, Murray A, Mazzeo CI, Tudor C, et al. Placentation defects are highly prevalent in embryonic lethal mouse mutants. Nature 2018;555:463-8.

60. Yu S, Liu F, Wang C, Zhang J, Zhu A, Zou L, et al. Role of oxidative stress in liver toxicity induced by nickel oxide nanoparticles in rats. Mol Med Rep 2018;17:3133-9.

61. Dobrzyńska MM, Gajowik A, Radzikowska J, Lankoff A, Dušinská M, Kruszewski M. Genotoxicity of silver and titanium dioxide nanoparticles in bone marrow cells of rats in vivo. Toxicology 2014;315:86-91.

62. Reliene R, Hlavacova A, Mahadevan B, Baird WM, Schiestl RH. Diesel exhaust particles cause increased levels of DNA deletions after transplacental exposure in mice. Mutat Res 2005;570:245-52.

63. Balansky R, Longobardi M, Ganchev G, Iltcheva M, Nedyalkov N, Atanasov $\mathrm{P}$, et al. Transplacental clastogenic and epigenetic effects of gold nanoparticles in mice. Mutat Res 2013;751-752:42-8.

64. Jackson P, Halappanavar S, Hougaard KS, Williams A, Madsen AM, Lamson JS, et al. Maternal inhalation of surface-coated nanosized titanium dioxide (UV-Titan) in C57BL/6 mice: Effects in prenatally exposed offspring on hepatic DNA damage and gene expression. Nanotoxicology 2013;7:85-96.

65. Dumala N, Mangalampalli B, Kamal SS, Grover P. Repeated oral dose toxicity study of nickel oxide nanoparticles in Wistar rats: A histological and biochemical perspective. J Appl Toxicol 2019;39:1012-29.

66. Horie M, Fukui H, Nishio K, Endoh S, Kato H, Fujita K, et al. Evaluation of acute oxidative stress induced by $\mathrm{NiO}$ nanoparticles in vivo and in vitro. J Occup Health 2011;53:64-74.

67. Morimoto Y, Oyabu T, Ogami A, Myojo T, Kuroda E, Hirohashi M, et al. IInvestigation of gene expression of MMP-2 and TIMP-2 mRNA in rat lung in inhaled nickel oxide and titanium dioxide nanoparticles. Ind Health 2011;49:344-52.

68. Ahamed M, Akhtar MJ, Siddiqui MA, Ahmad J, Musarrat J, AlKhedhairy AA, et al. Oxidative stress mediated apoptosis induced by nickel ferrite nanoparticles in cultured A549 cells. Toxicology 2011;283:101-8

69. Sutunkova MP, Solovyeva SN, Minigalieva IA, Gurvich VB, Valamina IE, Makeyev OH, et al. Toxic effects of low-level long-term inhalation exposures of rats to nickel oxide nanoparticles. Int J Mol Sci 2019;20:1778

70. Yokota S, Mizuo K, Moriya N, Oshio S, Sugawara I, Takeda K. Effect of prenatal exposure to diesel exhaust on dopaminergic system in mice. Neurosci Lett 2009;449:38-41.

71. Sugamata M, Ihara T, Takano H, Oshio S, Takeda K. Maternal diesel exhaust exposure damages newborn murine brains. J Health Sci 2006;52:82-4

72. Jackson P, Vogel U, Wallin H, Hougaard KS. Prenatal exposure to carbon black (printex 90): Effects on sexual development and neurofunction. Basic Clin Pharmacol Toxicol 2011;109:434-7.

73. Watson RE, Desesso JM, Hurtt ME, Cappon GD. Postnatal growth and morphological development of the brain: A species comparison. Birth Defects Res B Dev Reprod Toxicol 2006;77:471-84.

74. Lee Y, Choi J, Kim P, Choi K, Kim S, Shon W, et al. A transfer of silver nanoparticles from pregnant rat to offspring. Toxicol Res 2012;28:139-41

75. Wang J, Zhou G, Chen C, Yu H, Wang T, Ma Y, et al. Acute toxicity and biodistribution of different sized titanium dioxide particles in mice after oral administration. Toxicol Lett 2007;168:176-85.

76. Hu R, Zheng L, Zhang T, Gao G, Cui Y, Cheng Z, et al. Molecular mechanism of hippocampal apoptosis of mice following exposure to titanium dioxide nanoparticles. J Hazard Mater 2011;191:32-40.

77. Engler-Chiurazzi EB, Stapleton PA, Stalnaker JJ, Ren X, Hu H, Nurkiewicz TR, et al. Impacts of prenatal nanomaterial exposure on male adult Sprague-Dawley rat behavior and cognition. J Toxicol Environ Health A 2016;79:447-52. 
78. Ghaderi S, Tabatabaei SR, Varzi HN, Rashno M. Induced adverse effects of prenatal exposure to silver nanoparticles on neurobehavioral development of offspring of mice. J Toxicol Sci 2015;40:263-75.

79. Lee S, Hwang SH, Jeong J, Han Y, Kim SH, Lee DK, et al. Nickel oxide nanoparticles can recruit eosinophils in the lungs of rats by the direct release of intracellular eotaxin. Part Fibre Toxicol 2016;13:30.

80. Kanold JM, Wang J, Brümmer F, Šiller L. Metallic nickel nanoparticles and their effect on the embryonic development of the sea urchin Paracentrotus lividus. Environ Pollut 2016;212:224-9.

81. Duan WX, He MD, Mao L, Qian FH, Li YM, Pi HF, et al. NiO nanoparticles induce apoptosis through repressing SIRT1 in human bronchial epithelial cells. Toxicol Appl Pharmacol 2015;286:80-91.
82. Faisal M, Saquib Q, Alatar AA, Al-Khedhairy AA, Hegazy AK, Musarrat J. Phytotoxic hazards of NiO-nanoparticles in tomato: A study on mechanism of cell death. J Hazard Mater 2013;250-251:318-32.

83. Kawanishi S, Oikawa S, Inoue S, Nishino K. Distinct mechanisms of oxidative DNA damage induced by carcinogenic nickel subsulfide and nickel oxides. Environ Health Perspect 2002;110 Suppl 5:789-91.

84. Cempel M, Janicka K. Distribution of nickel, zinc, and copper in rat organs after oral administration of nickel(II) chloride. Biol Trace Elem Res 2002;90:215.

85. Saini S, Nair N, Saini MR. Embryotoxic and teratogenic effects of nickel in Swiss albino mice during organogenetic period. Biomed Res Int 2013;2013:701439. 